\title{
THE APPLICATION OF PLANING TOOLS DURING TURNING
}

\author{
Leszek Tomczewski ${ }^{1}$ \\ 1 Faculty of Mechanical Engineering and Aeronautics, Rzeszow University of Technology, al. Powstańców \\ Warszawy 8, 35-959 Rzeszow, Poland, e-mail: Itktmiop@prz.edu.pl
}

Received: 2015.06.02

Accepted: 2015.08.05

Published: 2015.09.01

\begin{abstract}
The articles presents the possibility of using CNC turning centers for planing. Through the application of specialized planingtools, it is possible to avoid the use of additional mills during the machining process. The implementation of these tools avoids dimensional and geometrical deviations resulting for remounting the work piece in different machines, while also saving time.
\end{abstract}

Keywords: turning, planing, planing tools.

\section{INTRODUCTION}

Machining is only one method of manufacturing, it includes the shaping of machine parts and devices through the removal of excess material in the form of chips. It is a variation of subtractive manufacturing [1]. Machining can be subdivided as presented in Figure 1.

Subtractive manufacturing is commonly used because of its universalness, ability to achieve complex geometry, the properties of the machined surface, and the ability to shape different types of material. Chip machining is done through use of a tool that has precisely determined blade number and shape. The two main types of chip machining are shaping and planing They are characterized by $[2,3]$ :
- a linear reciprocating main translation. During shaping the movement occurs within the horizontal plane, while during planing it occurs in the vertical plane.

- an interrupted linear or curved auxiliary sliding movement that occurs during the end of the idle stroke.

Depending on the main movement that is done, shaping can be divided into:

- longitudinal shaping - the main translation is done by the work piece, while the auxiliary translations are done by the tool;

- transverse shaping - the main translation is done by the tool, while auxiliary translations are done by the work piece:

- horizontal, - vertical (planing).

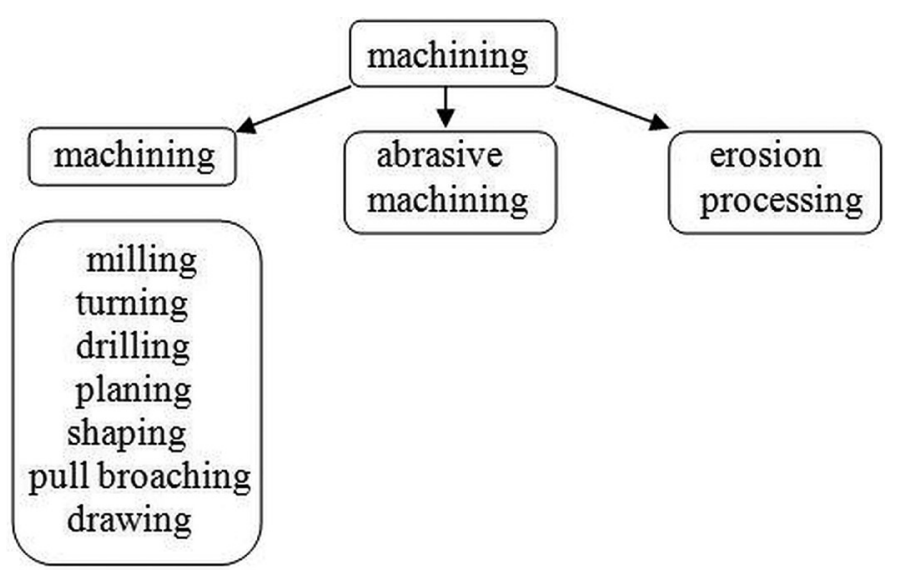

Fig. 1. The division of machining processes 
Shaping and planing both have a high level of machining accuracy, and are capable of machining places that are difficult to access. The main fault of these processes is the occurrence of the return idle stroke. These processes are done on shapers and planers. These machine tools are capable of machining flat and curved surfaces. Layers of material are removed through a linear translation at a set width, length and height by these machine tools. Machining occurs during each linear translation that is followed by an idle stroke and slide. The last two movements exist to reset the tool and prepare to remove the following layer of material.

\section{PLANING ON A CNC TURNING CENTER}

Tools used for shaping and planing are mainly used to produce spline grooves, polygonal holes, and surfaces and holes composed of different shapes. Gears are manufactured through Fellow's method or by implementing the MAAG gear cutting methodology.

Longitudinal and transverse shaping machine tools and planers are used for these processes. Planing can be done on contemporary general purpose mills, which are equipped with planing option (Figure 2). The structure of shaping tools is very similar to the structure and geometry turning tools. They are made of a lengthened mounting shank and a narrow work end.

Shaping and planing can also be done on $\mathrm{CNC}$ turning centers. These processes can be done by using planing tools, which are a just one example of such tool ends. An example of a planing tool can be seen in Figure 3.
The machining of splines and grooves on a turned work piece requires additional, time intensive, remounting of the work piece for broaching or planing on a different machine tool. This requires preparing an additional machine tool, additional configuration, and costs that arise from working with additional machine tools. Implementing these tools allows for spline and groove machining on $\mathrm{CNC}$ turning centers in their basic configuration for manufacturing different elements.

Figure 4 presents the process of planing a groove on the HAAS ST20 turning center by applying the HORN SH117.0025.2.10 planing tool. The machine is equipped with an additional $\mathrm{C}$ axis, which is necessary in the machining of multiple grooves spaced in a set offset on the circumference of the hole. This is accomplished by implementing indexing. The S117 tool system is available for wide grooves (wider than $4 \mathrm{~mm}$ ). The standard depth of the grooves is between $40 \mathrm{~mm}$ and $50 \mathrm{~mm}$, depending and the type of chuck. These tools can machine grooves through the entire length of the material or even grooves that end in a relief turn (Figure 5).

The tool is mounted to the head of the machine tool using standard chucks. The use of a cooling agent improves the surface properties of the grooves, washes away grooves, and increases tool life. The manufacturer recommended work parameters, for this type of tool, are presented in Figure 6 [6]. The values displayed below are only guides. The selection of the correct parameters depends on many factors like the type of material and the dimensions of the groove.

Figure 6 present a fragment of the NC program code used in shaping grooves. All the key information is presented at the beginning of the

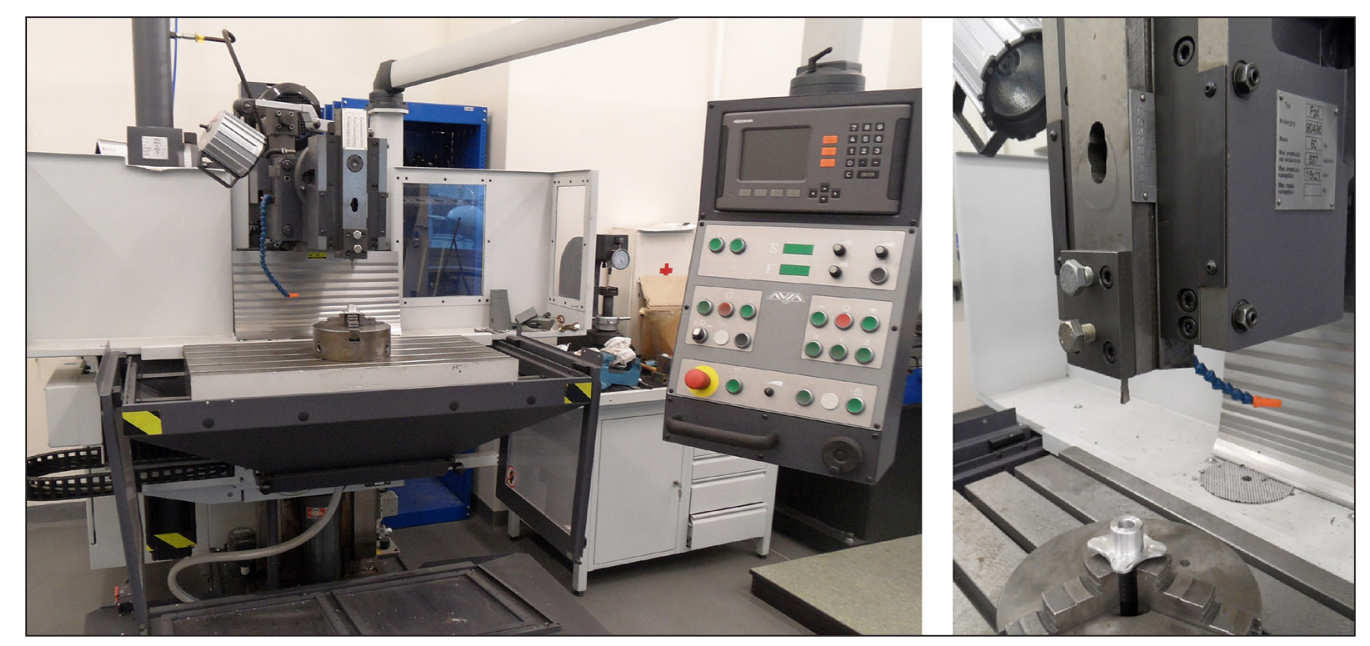

Fig. 2. Universal mill AVIA FNX 40N 


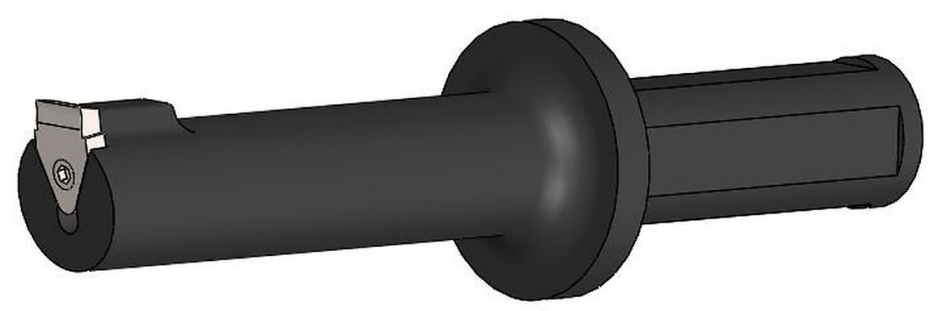

Fig. 3. Planing tool model

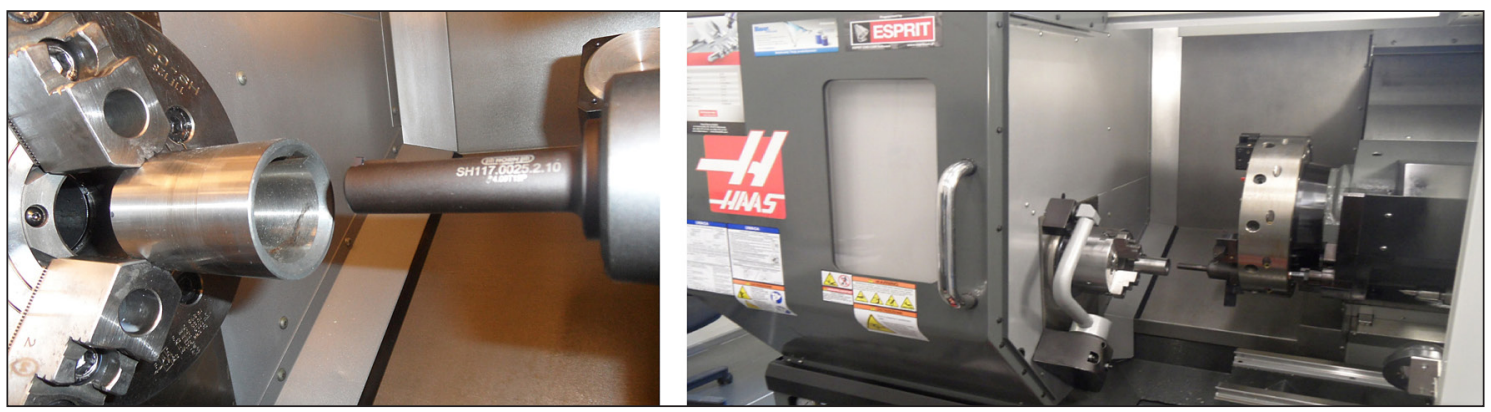

Fig. 4. Planing on a HAAS ST20 turning center
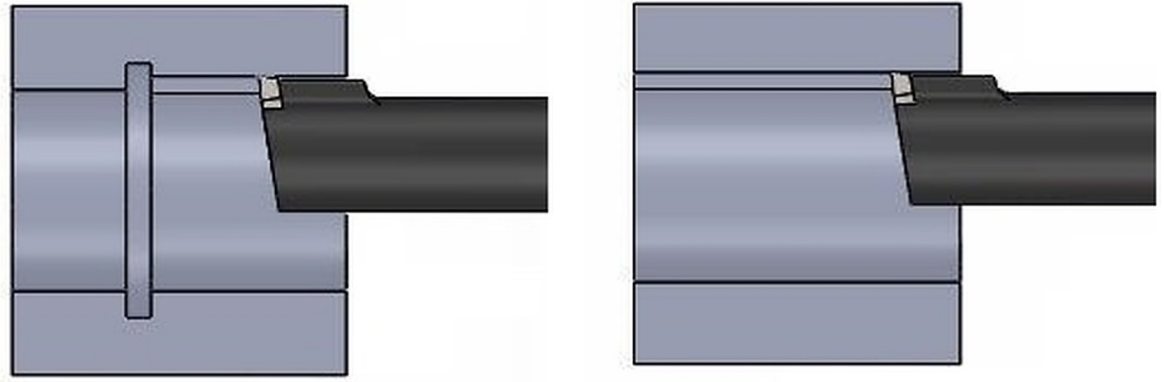

Fig. 5. Machining grooves

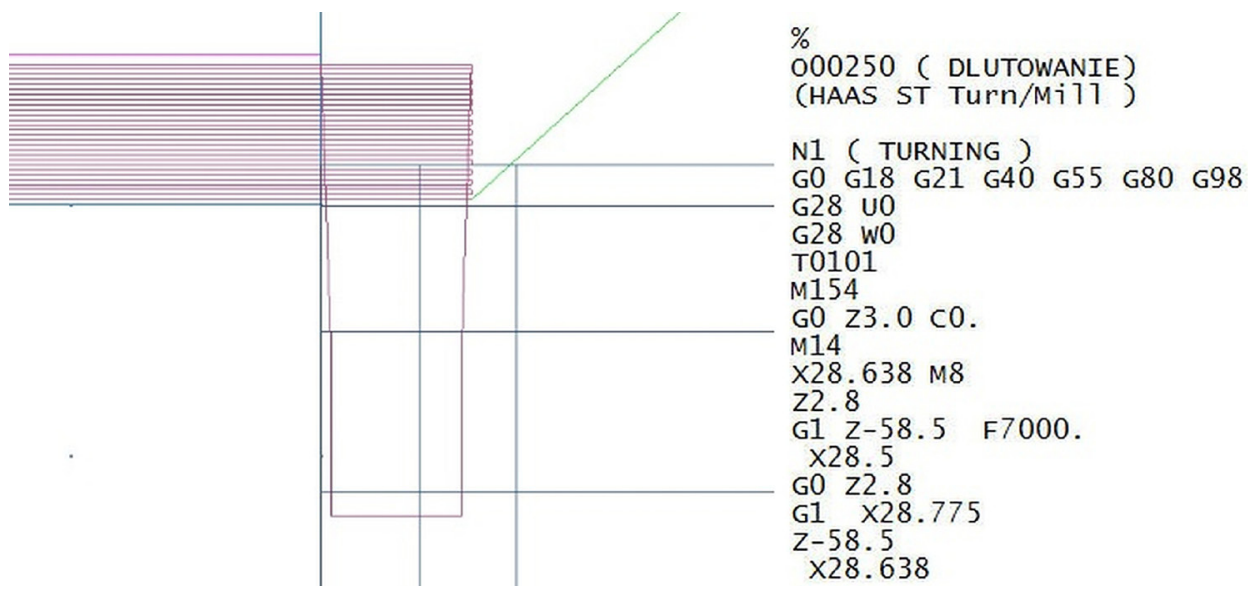

Fig. 6. Machining simulation, and a fragment of the NC program code

program (tool selection, programing base, and work parameters). During planing it is important to engage the clutch of the auxiliary $\mathrm{C}$ axis, this is accomplished command G154 and by setting the correct angular $\mathrm{C} 0$ position. An additional step is the engagement of a brake on this axis, to ensure that the spindle is stationary (function m14) [7]. In the following lines of the work translations are done to determine depth, as well as the return setting translation.

To machine a groove on a $\mathrm{CNC}$ turning center, the following parameters were selected. Feed 
speed $7000 \mathrm{~mm} / \mathrm{min}$ and a layer machining depther of $0.07 \mathrm{~mm}$. The through groove was machined in a sleeve with a $30 \mathrm{~mm}$ internal diameter and $50 \mathrm{~mm}$ length. The machined groove was measured to determine the roughness. The measured parameters were: the mean of the offsets from the average Ra line. The measurement was done on the surface of the groove. Depending on the type of machining, the following results appear in current literature [8]:

- rough shaping $\mathrm{Ra}>12.5 \mu \mathrm{m}$;

- precision shaping Ra from $1.6 \mu \mathrm{m}$ to $6.3 \mu \mathrm{m}$;

- planing Ra from $2 \mu \mathrm{m}$ to $8 \mu \mathrm{m}$.

The measurements of roughness done on the Surtronik $3+$ profiler. The surface measurement was done thrice. The average $\mathrm{Ra}$ value was 0.7 $\mu$ mon the surface of the groove.

\section{CONCLUSIONS}

The described method of machining can be applied in the production of single elements because it is a very intensive method when compared the traditional method of using planers and shapers. CAD/CAM software and $\mathrm{CNC}$ turning centers with the additional planing $\mathrm{C}$ axis can run many different machining process, not just turning, with one mounting of the work piece with the correct tools. When machining a groove in a sleeve, the average roughness parameters are similar to precision planing. These parameters, however, can differ on different types and hardness values of materials, and the dimensions of the groove.

Planing on a CNC turning center avoids dimensional and geometrical deviations resulting for remounting the work piece in different machines, while saving time that would otherwise used on remounting the work piece in a different machine tool.

\section{REFERENCES}

1. Oczoś K.E.: Sposoby kształtowania ubytkowego. Klasyfikacja i terminologia. Mechanik, 2, 2005 , 57-59.

2. Poradnik inżyniera. Obróbka skrawaniem. Vol. 2. WNT, Warsaw 1993.

3. Brodowicz W.: Skrawanie i narzędzia. WSiP Publishing, Warsaw 1989.

4. Storch B.: Podstawy obróbki skrawaniem. Publishing of Koszalin University of Technology, Koszalin 2001 .

5. Stós J. (Ed.): Obróbka skrawaniem w praktyce. Verlag Dashofer Publishing, Warsaw 2009.

6. Catalogue of HORN.

7. User manual HAAS.

8. Kurmaz L., Kurmaz W.: Podstawy konstruowania węzłów i części maszyn. Kielce University of Technology, Kielce 2011. 